\title{
V. O. CHIDAMBARAM AND HIS PRISON LIFE - A STUDY
}

\section{R. DHANABAL}

Assistant Professor in History, Government Arts College for Women, Salem, Tamil Nadu, India

V. O. Chidambaram a Prominent national leader from Tamil Nadu, Participate in the freedom struggle of India by taking measures to crab all his influence and popularity in the down south among the people, they also wanted to suppress the Swadeshi Movement, because in the South V.O.C started the Swadeshi Navigation company. V.O.C spent his most of his jail life in the Coimbatore jail. Where tortures inflicted on him were numerous.
\end{abstract}

KEYWORDS: Swadeshi Movement, Suppress of the British \& Torture Faced by V.O.C in Coimbatore Jail

Received: Mar 01, 2019; Accepted: Mar 21, 2019; Published: Apr 16, 2019; Paper Id.: IJEEFUSJUN20192

\section{INTRODUCTION}

The imprisonment of V.O.C. and Siva made a very great impact upon the people of Tirunelveli, it witnessed the Tirunelveli Riots, etc. Having seen all these the British wanted to protect their interest. They went with a two prolonged approach in dealing with the national patriot V.O.C.

- By humiliating and ill-treating him, inhumanly in the prison, with an eye to break his back bone of courage, determination and patriotism i.e., oppression inside the prison.

- By taking measures to curb all his influence and popularity in the down south among the people. They wanted to suppress the Swadeshi movement and her child in the down south, namely the 'Swadeshi Navigation Company'. Pillai was treated very unceremoniously and the torture inflicted on him were numerous in prisons.

\section{OPPRESSION INSIDE}

Chidambaram Pillai spent most of his jail life in the Coimbatore Central Jail. Due to the torturous sufferings in the prison Chidambaram Pillai was growing weaker day by day. When he went to prison, his weight was 130 pounds. But, within six months after his imprisonment, his weight had come by 27 pounds and became very weak.

While Pillai was struggling for life, the jail superintendent, E. H. Gadsden, ordered him to do arduous labour. Chidambaram Pillai was made to draw oil-press like a beast, with fetters on his hands and legs. It was reported in India on 28 November, 1908 as quoted below: "Alas! The heart flutters when we think of his cruel treatment and the hand trembles when we write about it"

He was even fainted while working. Pillai did not shed tears thinking of the miseries that he had to suffer. While he was toiling with the country type oil-mill, he imagined as if he was going round the divine abode of free Bharathamatha and also spent his time in literary pursuit. 
He was able to complete the translation of the English book "As a man thinketh" by James Alien under the title "Manampol Valvu' and the proceeds of the sale was given to his family for their upkeep and the Indians settled in South Africa also a few people in India helped the family for their maintenance.

Although he had been sentenced to transportation, he was kept in Indian jail since the government of India has prohibited deportation of prisoners to Andamans because of overcrowding in the jails there. V.O.C. submitted several petitions to the Madras Government, the Indian Government and His Majesty, King emperor expressing that he could not bear and tolerate the inhuman treatments caused to him in prison and requesting that he be transported to the Andamans or at least to some other jails. Through the newspaper, the horrible prison life of V.O.C. spread out all over south and all the youths were very furious about it.

He was beaten horribly and a voncit who involved in Tirunelveli was forced to eat even human excreta. He had also said that meals served out to him was full of mud and stone particles; and though all this was reported to the Inspector General of Police, no notice was taken up on it.

One day in prison, the Jailor asked V.O.C to do the work of a Scavenger. Pillai refused to do this even at the risk of his life. When he was undergoing the sentence in Coimbatore prison, V.O.C. had anticipated a tense situation with the Jailor. One night Sivakasi Arumugam Pillai, Vaduhu Ramanand some other senior convicts also came to V.O.C. and offered refreshments to him and one day Chidambaram Pillai, went to the jail office where Vaduhu Raman saluted him, on seeing this the jailor threatened Raman would be punished if he show respect to V.O.C. Raman got disgusted with this, consulted with this, consulted with three convicts and planned to murder the jailor, superintendent and the Doctor, on the next morning supervision. Nevertheless, by the advice of Arumugam Pillai the three convicts approached V.O.C. and asked his permission to murder them.

But V.O.C. advised them not to do any harm to the Superintendent, but they could make the Jailor leave his job. The three convicts accepted the same and went away. On $23^{\text {rd }}$ August, 1908 at about 3p.m. However, three convicts attacked the Jailor. There was an outbreak of riot among other convicts. The Superintendent and the warden opened fire. One convict died and 6 others were injured.' The administration suspected Chidambaram Pillai's involvement and it was felt it was rescue an attempt to make Pillai to escape from the Jail. Then Pillai was transferred to Cannanore Jail due to this reason. He was lodged in Cannanore Jail in 1911.

Mr. Reeze, a member of the British Parliament, raised questions in the British Parliament on the following days 9.6.1909, 18.8.1909 he asked the Government about the torture and inhuman treatment meted out on Mr. V.O.C. only evasive replies were given to him. This debate brought to light the deplorable sub-standard conditions in the jails of Madras Presidency. But the Parliament did not give a responsible reply to his queries.

\section{SUPPRESSION OUTSIDE}

When V.O.C. was in prison, there was a lot of happenings outside the prison. The Swadeshi Navigation Company underwent many problems and finally it was wound up within a short period. The affected British merchant sore minds, who knowing the support of the authorities had used their influence in all possible ways to crush the Swadeshi Navigation Company.

They wired to the Registrar of the Joint Stock Company to prosecute the Swadeshi Navigation Company, if they had failed to produce their half yearly balance sheet. Because of lacking of the forceful organizing drive of Chidambaram 
Pillai who is not there to hold the company this encouraged the British merchants of their much long waited readiness to use this opportunity to their gain. Due to this reason, the progress of the company was not so good and instead it slowly became defunct.

Mr. Ashe and Mr. Wynch seemed to have a determination to crush the Swadeshi Navigation Company as a revenge against the troubles they faced like the coral mills strike, which Mr. Ashe felt was due to the activities of Chidambaram Pillai on the information given by the European merchants.

Moreover Mr. Rengaswamy, advocate, also had a discussion with him secretly in this connection after the imprisonment of V.O.C. and the managers of the Coral Mills and British Navigation Company also informed Mr. Ashe in the same way against V.O.C. Hence Ashe wanted to side with his European brethren.

The continued confrontation between Swadeshi Navigation Company and British Navigation Company made the people to suffer and it was a very significant fact that the shareholders and directors of the Swadeshi Navigation Company have begun to entertain grave fears both as regards the money in the shape of shares and the action government upon Chidambaram Pillai.

As the British had done to impede the work of the Swadeshi Company, the officers of the Tuticorin port prevented one of the Swadeshi steamers from sailing, on a flimsy ground that it did not satisfy some port rules. This had created an alarm in the minds of the many shareholders of the company who had feared the worst state of the company.

With a view to quell the Swadeshi Navigation Company, the British Navigation Company resorted of all sorts of tactics. The British Navigation Company made a secret convention with Railway authorities that concession rates for goods transshipped by they would be allowed in the Railway including Ceylon Railways.

The Swadeshi Navigation Company needed further funds to keep it going. The great poet Bharathi in his magazine, 'India', requested the people to extend all of their help and support for the maintenance of the Swadeshi Shipping Company.

Slowly the Swadeshi Navigation Company began to languish, and the company showed an unsatisfactory balance sheet for the year ending 31, March 1909. Under the financial strains, the Swadeshi Navigation Company sold her "Galliahship" to the British-India Navigation Company. This sale news affected V.O.C. very much in the prison. This 'Surrender' came like a shock to the nationalist India and persons like Bharathi, who was in voluntary exile in Pondicherry, exclaimed it would have been sunk in the Bay of Bengal. The Swadeshi Navigation Company failed because of the hostility of the Government and the promoters lacked the business ability and experience.

However, it is an apparent that not only was the Governmental indifferent to the Industrial development, but under the influence of European commercial and industrial interests, it was generally antagonistic to the development of the shipping industry in India.

The conviction of V.O.C. and Siva, witnessed the shooting and death of four persons during Tirunelveli riots on $13^{\text {th }}$ March, 1908, and the gradual failure of the Swadeshi Steamship Company and the repressive measures unleashed by the government had a profound impact in the minds of people and it made radical youths to get united together and they formed a revolutionary organization called 'Bharatha Matha Sangam'. The members took a pledge willingly to sacrifice their health, wealth and their lives for the cause of the nation. 
The Militant youths who had taken refuge in Pondicherry maintained contacts with the other Indian revolutionaries in London, Paris and other foreign countries, and as well as in India. The revolutionaries in Tamil Nadu were led by V. D. Sawarkar' trusted lieutenant V. V. S. lyer and they propagated terrorism.

Meanwhile, Ashe became the collector of Tirunelveli District. The agitators in Pondicherry resolved to take vengeance on him for the atrocities committed by him when he was a sub-collector, and they planned to kill him, accordingly collector Ashe was assassinated on $17^{\text {th }}$ June, 1911, while travelling in train to Kodaikkanal, by a radical militant patriotic youth, by name Mr. Vanchinathan, at Maniyachi Junction, and he also immediately committed suicide by the help of his pistol on search by the authorities one of the letters in his shirt pocket indicated that he had planned to assassinate Mr. Ashe only because he was responsible for the great cruelty inflicted upon Chidambaram Pillai.

The news of the assassination of collector Ashe, reached the ears of Pillai. He did not like the young men losing their valuable lives by following violent path, and he felt that this method cannot bring an end to the British rule. Meanwhile the questions of Royal Clemency to the prisoners on the occasion of coronation durbar was examined on $10^{\text {th }}$ August 1911. The criminal Investigation Department stated that Pillai was a thoroughly disloyal man and he was the instigating factor in the murder of Ashe, hence clemency to him was totally unjustifiable.

The Tirunelveli District Magistrate also had the same opinion and stated that V.O.C. had many admirers and sympathizers in the district. However, the Govemo-ill-council was prepared to suspend the sentence of V.O.C on certain conditions. But the suspension did not materialize and only a remission of 6 months was granted.

The sufferings of V.O.C. became more public when Mr. D. Subrathnam who was confined in the Caimanore prison, was released on 21.11.1911, wrote to the Editor of 'The Hindu about the pathetic treatment of V.O.C. The latter was transferred about a year back to Cannanore prison and he lost more than 20lbs on account being put on ragi diet. Initially when Ragi diet was introduced he refused to eat by starving one full day for which he was fined three days to the original punishment, finally he had to Succumb. The I.G. of prisoners, Mr. R. J. Macnamara, admitted that Chidambaram Pillai has lost six pounds of weight. Of all the allegations and counter exploitations, anything is clear that is V.O.C. has lost weight in many pounds with the introduction of ragi diet.

\section{CONCLUSIONS}

At last, he was released from Cannanore Jail on $24^{\text {th }}$ Dec. 1912. He earned the following remission, are mission of 92 days out of which '37' days was cancelled for jail offences committed on different occasions. Remission by way of proclamation for 6 months. Accession for 3 months, and Delhi Durbar 6 months. Totally the remission came to one year, 3 months and 55 days.

Before releasing him, the Government of Madras ordered a careful watch over V.O.C. After his release, it instructed that such, watch should be unobtrusive and if he showed signs of renewing seditions agitation, a more open surveillance would be necessary and if any people of influence associated with him, the District or Sub-Divisional Magistrate should send for them and warn them." The effort was made to isolate

The measures taken by the government, both inside and outside the prison had its own effect, and it is evident on his release, and when Chidambaram Pillia came out of the jail, there was little reception. This was perhaps because of the fear of the government or of the changed political atmosphere or probably both. 


\section{REFERENCES}

1. G.O.No.1719, Judicial Department (Ordinary) (MS) dt. 25.12.1908; G.O.No.1390, Judicial Department (MS) dt. 14.10.1909.

2. M.N.N.R., India, November 28, 1908.

3. Ibid.

4. India, December 5, 1908; Gothanda Raman, P., Indian Puratchi Iyakkam, New Century Book House, Madras, 1978, p.169.

5. G.O.No.248, Judicial Department (MS) dt. 17.2.1909.

6. M.N.N.R., Swadeshamitran, December 5, 1908.

7. El Sebaei, Mohamed. Prison in Persian and Arabic Alhabsiaat.

8. Subramaniam, V.Q.C., (Ed.,) Va. Vu. Chi. Suvacharithai Mullai Pathippakam, Chennai, 1946, p.114.

9. G.O.No.1416, Judicial Department (Confdl) (MS) dt. 15.10.1908, pp.1.

10. M.N.N.R., Swadeshamitran, March 2, 1908; The Hindu, April 3, 1908.

11. M.N.N.R., The Indian Patriot, April 2, 1908.

12. M.N.N.R., Nadegannadi, May 2, 1908.

13. Sadasivam, D., The Growth of Public Opinion in the Madras Presidency, 1885-1909, Madras University, Madras, 1974, p.107.

14. Tinnevelli Riots Conspiracy and Ashe Murder. Part-I, Records of Fort St. George, Madras, p.XVI.

15. G.O.No.1837, Judicial Department (Confdl) (MS) dt. 28.11.1911; Sedition Committee Report, Govt. Press, Calcutta, 1918.

16. Sivagnanam, Ma. Po., Viduthalai Poril Tamizhagam, Vol. I, Poonkodi Pathippakam, Madras, 1982, p.262. 
